\title{
Characterization of main external climate influences in rainfall and air temperature in the Paute River Basin - Southern Andes of Ecuador
}

\author{
D. E. Mora ${ }^{1,2}$, P. Willems ${ }^{1,3}$ \\ ${ }^{1}$ Katholieke Universiteit Leuven, Hydraulics Divison, Kasteelpark Arenberg 40,3001 Heverlee, \\ Belgium \\ ${ }^{2}$ Universidad de Cuenca, Av. 12 de abril, Cuenca, Ecuador \\ ${ }^{3}$ Vrije Universiteit Brussel, Department of Hydrology \& Hydraulic Engineering, Pleinlaan 2, 1050 \\ Brussels, Belgium
}

Autor para correspondencia: diego.moraserrano@bwk.kuleuven.be

Fecha de recepción: 29 de mayo de 2011 - Fecha de aceptación: 27 de juli de 2011

\begin{abstract}
Characterization of climate variability in the Andes mountain range needs special assessment as rainfall and temperature are extremely variable in space and time. This paper examines the anomalies of observed month rainfall and temperature data of respectively 25 and 16 stations, from the early 1960 's to the 1990's and compare them against anomalies from different external climate influences in annual and 3-month seasonal block periods. The stations are located in the Río Paute Basin in the Ecuador's southern Andes. All stations are within the elevation band 1800 and $4200 \mathrm{~m}$ a.s.l. and affected by the Tropical Pacific, Amazon and Tropical Atlantic climate. The results show similar temperature variations for the entire region, which are highly influenced by the ENSO, especially during the DJF season. During JJA, the correlation is weaker showing the influence of other climate factors. Higher temperature anomalies are found at the high elevation sites while in deep valleys the anomalies are less significant. Rainfall variations depend, in addition to elevation, on additional factors such as the aspect orientation, slope and hydrological regime. Highest and most significant rainfall anomalies are found in the eastern sites.
\end{abstract}

Keywords: Mountain environments, Ecuadorian Andes, Paute Basin, climate variability, climate anomalies, ENSO, quantile perturbation approach.

\section{RESUMEN}

Caracterización de la variabilidad climática en la Cordillera de los Andes necesita un de un análisis especial debido a que en esto región, la precipitación y temperatura ser extremadamente variables tanto a escala espacial como en escala temporal. En este artículo se examina las anomalías de datos mensuales de precipitación y temperatura media observada en 25 y 16 estaciones respectivamente, que datan desde inicios de 1960 hasta 1990, y los compara versus las anomalías de diferentes influencias climáticas externas de la región en bloques de periodos anuales y trimestrales. Las estaciones están ubicadas en la cuenca del Río Paute en el sur de los andes ecuatorianos. Las estaciones se encuentran en un rango de elevación entre 1800 y 4200 m s.n.m. y principalmente están afectados por influencias climáticas externas correspondientes al Pacifico tropical, la Amazonía y el Atlántico tropical. Los resultados muestran variaciones de temperatura homogéneas en toda la región, las mismas que están altamente influenciadas por el ENSO (El Nino South Oscillation) especialmente durante el trimestre Diciembre-Enero-Febrero. Durante Junio-Julio-Agosto, la correlación es menor, mostrando posibles influencias de otros factores climáticos. Se encontró valores altos y significativos de anomalías en temperatura en sitios de alta elevación, mientras que en los valles interandinos las anomalías son menores y de menor grado significativo. La variación en precipitación depende, además de la elevación, a factores adicionales como la orientación del terreno, la pendiente y el 
régimen hidrológico. Los valores altos y significativos de anomalías en precipitación fueron encontrados en los sitios ubicados en la región oriental de la cuenca.

Palabras clave: Sistemas de montañas, Andes ecuatorianos, cuenca del Río Paute, variabilidad climática, anomalía climática, ENSO, método de perturbación-cuantil.

\section{INTRODUCTION}

Climate variability and change will play an increasing role in economic and social decisions at regional, national and international level. According to the fourth IPCC report for South America, the main impacts in the region are a clear increase in mean surface temperature, disappearance of glaciers in Colombia, Ecuador, Peru and Bolivia (Vuille et al. 2008), higher variability in extreme rainfall events (Parry et al. 2007) and decreasing rainfall depths for the Amazon Basin (Villar et al. 2009). Ecosystems might be drastically affected as a result of longer drought periods and higher intensity rainfalls that could cause more frequent floods (Parry et al. 2007; Buytaert et al. 2010). In support of the planning and design of mitigation measures, it is highly important to determine the main climate trends in the region. Since, as stated by Villar et al. (2009), the Andes region in the Amazon Basin, including the South Ecuadorian Andes, shows the highest weather and climate variability it is important to understand the drivers that influence the climate at local scale and to relate the drivers to the variations and trends observed in local weather stations.

The climate in the tropical region in north-west South America is dominated by the Inter-tropical Convergence Zone (ITCZ) and the South Atlantic Convergence Zone (SACZ), and therefore under the influence of the climate anomalies of the South America Monsoon System (SAMS) and the El Niño Southern Oscillation (ENSO). Linked to the ENSO, strong positive sea surface temperature anomalies along the coast of Ecuador and northern Peru bring torrential rains, high river runoff and flooding, additional to an intensification of the Inter-Tropical Convergence Zone (ITCZ) over the eastern Pacific. These periods are called El Niño events. Strong negative sea surface temperature anomalies, La Niña events, bring low temperatures, dry seasons and stress in water availability.

The ENSO is one of the main climate anomalies that drive the region, including the Andean region. Marengo (2009) indicated that ENSO variability was detected in rainfall in the northern Amazon with a low-frequency variability, meaning that ENSO might influence the Andes but at a lower magnitude. However, he also stated that multi-decadal variations of rainfall in the Amazon might be linked to SSTs in the subtropical Atlantic. Meanwhile, Francou (2004) indicated a strong dependence of ENSO on the Antizana mountain ablation-snowfall in the north of Ecuador.

Bendix et al. (2006) investigated the dynamics of heavy rainfall during El Niño events in the coastal area of Ecuador and northern Peru. Their study developed 16 factors each one with different specific weather situations that could lead to moist instability and heavy rainfall during El Niño events. Three of their factors, which explain nearly half of the total rainfall variance, are linked to well-developed rainfall in the Amazon region crossing the Andes over the Ecuador region and that ends in heavy rainfall in the coastal region. Hence, heavy rainfall during El Niño events, according to these factors, can originate from weather patterns that are also relevant in non-El Niño periods. We learn from that research that, although a moderate positive SST anomaly off the coast causes an intensification of rainfall in the coastal area of Ecuador and northern Peru during El Niño, it is not the only factor that controls rainfall extremes. Wang et al. (2007) indicated that ENSO variability is most pronounced along the equator and the coast of Ecuador and Peru, developing strong or weak ENSO events. This variation might be caused by westerly wind anomalies produced in the Equatorial Western Pacific and led the Nino3 SST anomalies by about four months. It suggests that the Western Pacific is an important region for defining the ENSO variability and its influence on the coast of Ecuador and Peru.

The effects of the ENSO and the ITCZ anomalies are highly visible in the Coastal Pacific region, but the effects are less clear and little is known about the influence of factors inland through the Andes mountains and far in the Amazon forest. The high heterogeneity of climate parameters in the 
inland region, for both rainfall and temperature, is one of the reasons that lead to this research. Vuille et al. (2000) took different weather stations along the Ecuadorian Andes and found that the rainfall variability in the Andes area of Ecuador is related to the sea surface temperature anomalies in the Pacific. They also found that this ENSO influence is most dominant in the region during DecemberFebruary (DJF) and also strongly influences the Eastern Cordillera (Real Cordillera) during JuneAugust (JJA). In both cases, below or above average rainfall is associated with El Niño or La Niña events respectively (inverse of what occurs along the coastal front). They additionally concluded that the weather in the Eastern Cordillera in the other periods of the year is correlated to the ITCZ in the Tropical South Atlantic, and in few local areas in the south of the Eastern Cordillera between $1^{\circ}$ and $3^{\circ} \mathrm{S}$ the weather is correlated with the El Nino events in the period DJF. The study of Vuille et al. (2000) also concluded that temperature along the Ecuadorian Andes is largely correlated to sea surface temperature anomalies in the Tropical Pacific domain, following the response of ENSO Region $3\left(5^{\circ} \mathrm{N}-5^{\circ} \mathrm{S}, 150^{\circ} \mathrm{W}-90^{\circ} \mathrm{W}\right)$ and ENSO Region $3.4\left(5^{\circ} \mathrm{N}-5^{\circ} \mathrm{S}, 170^{\circ} \mathrm{W}-120^{\circ} \mathrm{W}\right)$. They additionally noticed that the weather in the Northern Cordillera is correlated with the Tropical North Atlantic sea surface temperature anomaly.

Taking this prior knowledge into account, this paper aims to explain historical variations in rainfall and temperature by means of the main external influences (teleconnections) for one of the river basins in the Southern Ecuadorian Andes, the Paute River Basin. This is done based on several observed local weather stations distributed along the basin, estimation of the decadal oscillations or anomalies, and testing of their significance for periods of 30 years. It is studied how the rainfall and temperature oscillations are related to oscillations of the external climate variables. These relationships might enable to determine future behaviors in the climate change context, as more knowledge (both in term of recent monitoring data and future scenario analysis) is available for these external climate variables.

The study makes use of the rainfall subregions that were identified for the Paute River Basin by Celleri (2007), see Figure 1. They identified the subregions based on inter-station correlation analysis in two steps: (i) the analysis of distribution of mean monthly precipitation to classify rainfall stations following contrasting rainfall regimes; and (ii) monthly timeseries analysis in an attempt to identify secondary rainfall patterns. This study resulted in four different rainfall regimes, based on the annual distribution of rain: an Andean inter-valley regime (BM1), a high páramo mountain regime (BM2), a medium Amazon inter-valley regime (UM1) and a stronger Amazon inter-valley regime (UM2). In the following the data and the applied methodology are described. This is followed by a section that presents and discusses the results of the temporal variations, as well as the correlation with the main large scale climate influences, for all the seasons and for 3-month seasonal periods. The final section summarizes the conclusions of the research and ends with some concluding remarks.

\section{METHODOLOGY}

\subsection{Study Region}

The Paute River Basin is located in the Inter-Andean Depression that separates the Western and Real Cordillera in the south of Ecuador (Coltorti and Ollier, 2000). The basin has an area of $5066 \mathrm{~km}^{2}$ up to an important hydropower plant. The elevation ranges from 1840 to $4680 \mathrm{~m}$ a.s.l. The upper part of the basin is located only $17 \mathrm{~km}$ from the Pacific coast in its western point and the downstream part ends in the interspersed region between the Andes and the Amazon regions.

\subsection{Data and filling gaps}

The Paute River Basin is one of the most monitored basins in Ecuador, particular since 1963 due to its importance in hydropower energy production. The monitored data is dispersed present in several databases ruled by different institutions: INAMHI (Instituto Nacional de Meteorología e Hidrología), INERHI (Instituto Ecuatoriano de Recursos Hídricos) and INECEL (Instituto Ecuatoriano de Electrificación). 

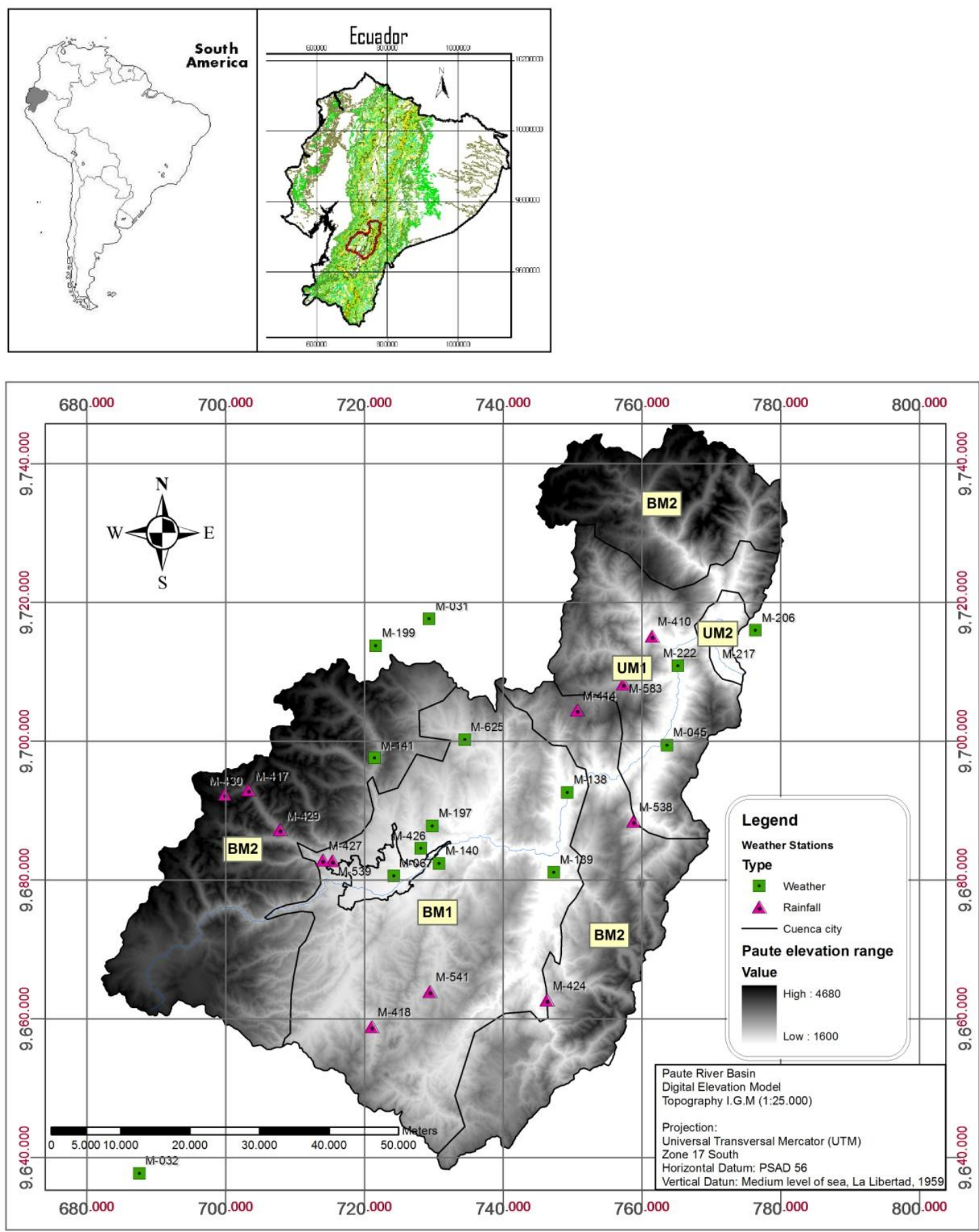

Figure 1. Location of the Paute River Basin - weather and rainfall stations.

In 1987, the "Plan Nacional de Riego" project INERHI-ORSTOM (Office de la Recherche Scientifique et Technique d'Outre-Mer, France) merged the different databases in one database called BIDRIE (Le Goulven et al., 1987). Unfortunately, monitoring was cancelled for most of the stations at the beginning of the 1990's due to the change of structure of governmental institutions (Galarraga, 2000). Data monitoring was continued only in few sites. However, local institutions monitored additional data in an independent way. Recent data is available at ETAPA (the drinking water authority for the city of Cuenca) for the period 1997-2004. These data, however, focus only in the western central region of the basin and lack spatial representation for the complete basin. In addition, INAMHI continued its monitoring only in two stations in the eastern region of the basin close to the 
hydro-power station. Since 1993 the Paute River Basin has less well distributed rainfall stations which could represent the rainfall regimes of the complete basin. For this research, data was compiled from the BIDRIE, INAMHI and ETAPA databases, resulting in 25 rainfall stations, 11 started in 1962-1964 and 14 in 1972-75 till 1992-1993, from which 3 with recent data from 1997-2004, and 17 weather stations starting around 1958-1962 till 1990-1992. Figure 1 and Table 1 give an overview of the stations of which data were used in this research.

Data on regional weather patterns (climate external influences) are available in several climate databases as the NOAA (National Oceanic and Atmospheric Administration) and ERA40 or ERA Interim databases. For this study, climate indices of NOAA were used. This includes data on ENSO anomalies in sea surface temperature (SST), for ENSO 1.2, ENSO 3, ENSO 3.4 regions and sea level pressure (SLP) at the Darwin-Tahiti station. Additionally, data corresponding to SST of the Tropical South Atlantic (SST TSA), the Tropical Pacific Oscillation (SST TPO) and the Eastern Pacific Oscillation (SST EPO) are also considered. Also Northeast Brazil Rainfall data were included, with data from a rain gauge in Fortaleza $\left(3.7^{\circ} \mathrm{S}, 38.5^{\circ} \mathrm{W}\right)$ in the Brazilian Amazon. The length of these climate records might differ. For this study, data covering the period 1968-1987 were selected.

Missing periods in the observed rainfall and temperature series were filled by means of multiple linear regressions (Carter and Benson, 1970). The method first applies a logarithmic transformation to the data and then converts the data to normalized standard variables. Based on the converted data, correlation coefficients are calculated between all pairs of stations, for each current and preceding month, and applied in the multiple linear regression equation. In order to maintain a reasonable number of correlation coefficients, stations are first ranked by rainfall regime (Celleri, 2007) and grouped in sets of 6 . In this way the number of correlation coefficients is limited to twelve: six from stations in the current month and six from the previous month. The number of coefficients is constant for all infillings. Villazon et al. (2010) compared the multiple linear regression approach with the more classical linear regression technique for gap filling of rainfall series in Bolivia and found an important reduction in the daily rainfall error (36\%) using the multiple linear regression technique.

\subsection{Anomalies}

To study the anomalies in rainfall and temperature, it is necessary to understand the historical variations in these series. Based on these variations, which reflect the natural temporal variability, it can be tested whether the recent trends are statistically significant.

\section{Quantile - perturbation approach}

Ntegeka and Willems (2008) proposed a methodology for the analysis of trends and anomalies in hydro-climate extremes based on quantile perturbations. The perturbations refer to relative changes between two series. One of the series is taken as reference or baseline series while the other is a subseries of interest. In this study, the reference series are taken as the full available historical series, while the subseries are block periods of interest (i.e. 10 years). The quantile perturbation approach is applied to monthly series of rainfall and average temperature.

The monthly values within a subseries (particular block of $L$ years) are ranked in descending order, where $i$ is the rank of a given month in the series. Based on this rank, the empirical return period $T_{L(i)}$ can be estimated according to Eq. (1) for each month in the subseries. The same calculations are applied to the full long-term series ( $N$ years), Eq. (2).

$$
\begin{gathered}
T_{L(i)}=\frac{L}{i} \\
T_{N(i)}=\frac{N}{i}
\end{gathered}
$$


MASKANA, Vol. 2, No. 1, 2011

Table 1. Temperature and rainfall stations in the Paute River Basin.

\begin{tabular}{|c|c|c|c|c|c|c|c|c|c|c|}
\hline \multicolumn{5}{|c|}{ Temperature stations (monthly data) } & \multicolumn{6}{|c|}{ Rainfall stations (monthly data) } \\
\hline $\begin{array}{l}\text { Station } \\
\text { Code }\end{array}$ & Station name & $\begin{array}{c}\text { Elevation } \\
\text { m a.s.l. }\end{array}$ & Aspect & $\begin{array}{c}\text { Mean } \\
\text { annual }\left({ }^{\circ} \mathrm{C}\right)\end{array}$ & $\begin{array}{l}\text { Station } \\
\text { Code }\end{array}$ & Station name & $\begin{array}{c}\text { Rainfall } \\
\text { regime }\end{array}$ & $\begin{array}{c}\text { Elevation } \\
\text { m a.s.l. }\end{array}$ & Aspect & $\begin{array}{c}\text { Mean } \\
\text { annual (mm) }\end{array}$ \\
\hline M199 & PATOCOCHA & 3401 & North-West & 8.2 & M625 & BIBLIAN & BM1 & 2640 & East & 852.4 \\
\hline M141 & EL LABRADO & 3260 & South & 8.4 & M541 & COCHAPAMBA QUINJEO & BM1 & 2760 & North-East & 816 \\
\hline M031 & CAÑAR & 3083 & East & 11 & M197 & JACARIN & BM1 & 2700 & North-East & 719.5 \\
\hline M197 & JACARIN & 2700 & North-East & 14 & M139 & GUALACEO & BM1 & 2360 & Flat-North & 729.4 \\
\hline M625 & BIBLIAN INECEL & 2640 & East & 13.6 & M140 & UCUBAMBA & BM1 & 2510 & Flat-North & 918.5 \\
\hline M426 & RICAURTE CUENCA & 2545 & Flat-South & 14.8 & M418 & CUMBE & BM1 & 2720 & North-West & 681.4 \\
\hline M067 & CUENCA AEROPUERTO & 2516 & Flat & 14.7 & M067 & CUENCA AEROPUERTO & BM1 & 2516 & Flat-South & 846.2 \\
\hline M140 & UCUBAMBA & 2430 & Flat - North & 15.7 & M426 & RICAURTE CUENCA & BM1 & 2545 & Flat-South & 894.6 \\
\hline M045 & PALMAS & 2400 & North-West & 14.8 & M138 & PAUTE & BM1 & 2289 & Flat-South & 735.8 \\
\hline M139 & GUALACEO & 2360 & Flat - North & 17.1 & M539 & BUENOS AIRES AZUAY & BM1 & 2810 & South & 843.6 \\
\hline M222 & INGPATA & 2360 & North-West & 14.6 & M420 & NABON & BM1 & 2750 & South & 786.9 \\
\hline M138 & PAUTE & 2289 & Flat - South & 17.3 & M427 & SAYAUSI & BM1 & 2780 & South-East & 988.1 \\
\hline M050 & ARENALES & 2200 & East & 14.1 & M414 & CHANIN & BM2 & 3020 & East & 1702.2 \\
\hline M217 & PENAS COLORADAS & 2000 & East & 14.1 & M424 & SIGSIG & BM2 & 2600 & North & 753 \\
\hline M206 & GUARUMALES & 1645 & South-East & 17.2 & M141 & EL LABRADO & BM2 & 3260 & South & 1280.5 \\
\hline \multirow[t]{10}{*}{ M032 } & SANTA ISABEL & 1550 & South-West & 19.2 & M430 & QUINOAS & BM2 & 3200 & South-East & 948.9 \\
\hline & & & & & M417 & PISCICOLA CHIRIMICHAY & BM2 & 3270 & South-East & 1256.7 \\
\hline & & & & & M429 & SURUCUCHO (LLULLUCHAS) & BM2 & 2800 & South-East & 873.4 \\
\hline & & & & & M583 & PINDILIG & UM1 & 2700 & East & 1076.2 \\
\hline & & & & & M410 & RIO MAZAR-RIVERA & UM1 & 2450 & East & 1305.7 \\
\hline & & & & & M538 & PANGRANDE & UM1 & 2600 & North-East & 1094.6 \\
\hline & & & & & M222 & INGPATA & UM1 & 2360 & North-West & 1321.6 \\
\hline & & & & & M050 & ARENALES & UM2 & 2200 & East & 3504.9 \\
\hline & & & & & M217 & PENAS COLORADAS & UM2 & 2000 & East & 3076.1 \\
\hline & & & & & M045 & PALMAS & UM2 & 2400 & North-West & 1587.5 \\
\hline
\end{tabular}


The monthly values that correspond to these return periods are denoted as the quantiles $x_{L}$, $x_{L / 2}, \ldots, x_{L / i}$ for the subseries and $x_{N}, x_{N / 2}, \ldots x_{N / i}$ for the full series. The perturbation factor $P_{(i)}$ for a given return period then corresponds to the ratio indicated in Eq. (3).

$$
P_{(i)}=\frac{x_{L}\left(T_{L(i)}\right)}{x_{N}\left(T_{N(i)}\right)}
$$

It is clear that the empirical return periods $T_{L(i)}$ of the subseries do not necessarily coincide with the empirical return periods of the full series $T_{N(i)}$. In that case, the $x_{N}\left(T_{L(i)}\right)$ values are derived by linear interpolation from the values with closest empirical return periods. From the perturbation factors of all months, an average perturbation factor can be calculated for all quantiles above a given threshold (or a given threshold for the return period). The average perturbation factors represent anomalies in quantiles, and are calculated in this paper for moving block periods (subseries of 10 years length, moved with 1-year step from the beginning, towards the end of the full available series). For a full series of $\mathrm{N}$ years $[0 ; \mathrm{N}]$, the following moving 10 -years subseries thus are considered: $[0 ; 10],[1 ; 11], \ldots,[\mathrm{N}-9 ; \mathrm{N}]$. The moving procedure causes dependency among the calculated anomalies (over periods of 10 years length), but allows easier visual interpretation of the temporal variations in these anomalies. The method allows detecting decadal and multi-decadal oscillations in extreme quantile anomalies (Ntegeka, et al., 2008). The same procedure is applied but limiting the return period and perturbation factor calculations to a given season (i.e. DJF: December-JanuaryFebruary, MAM: March-April-May, JJA: June-July-August, SON: September-October-November). In this case the particular block period (subseries) of interest will be limited to the months in the given season.

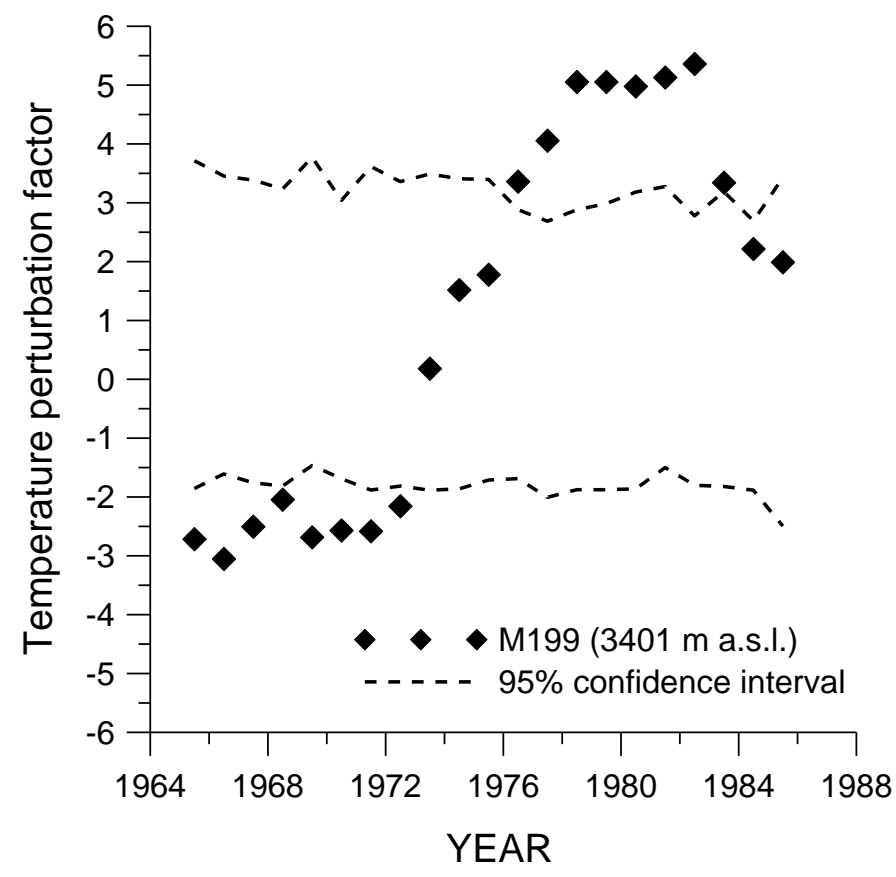

Figure 2. Quantile perturbation analysis results for temperature and $95 \%$ confidence intervals on the perturbation factors (all seasons, perturbation factor in percent).

\section{Significance testing}

Confidence intervals are calculated on the perturbation factors, under the null hypothesis of no trend or serial dependence in the occurrence of rainfall or temperature extremes in time. This is done to test whether the trends and anomalies identified in the historical series are significant. The confidence intervals are calculated by a non-parametric bootstrapping technique. The values in the full series are randomly resampled a large number of times (1000 bootstrap runs; each run containing the same number of values as in the full series). For each run, perturbation factors are recomputed, where after 
confidence intervals are calculated for each time step based on the ranked 1000 perturbation factors per time step. Since these confidence intervals define regions of expected variability under the null hypothesis, any anomaly value outside the confidence bounds is considered to be statistically significant (hypothesis of no trend or serial dependence is rejected), while the region inside the confidence bounds is considered insignificant (hypothesis accepted; see Figure 2).

\section{Correlation}

After determination of the anomalies for each of the stations, in both monthly rainfall and average temperature, together with the confidence intervals, comparison is made with the anomalies calculated in a similar way with data corresponding to regional climate influences as ENSO and ITCZ in the Pacific and the Atlantic. The aim of this comparison is to identify the external influences of the anomalies in rainfall and temperature. Sites with similar correlations are grouped to obtain regionalized estimates of the external influences.

The quantile-perturbation approach was compared with a simple regression after logarithmic transformation. Results show that correlation values are about 2 times higher when the quantileperturbation method is used, i.e. correlation coefficients between monthly rainfall at station M538 versus SST ENSO 1.2 and SST TSA equal $-0,77$ and 0,65 using the quantile-perturbation approach, while the direct regression with logarithmic transformation results in correlation coefficients of $-0,39$ and 0,31 , respectively. This is because the quantile-perturbation method filters out information on the statistical frequency properties of the variables under study, which may lead to more clear teleconnection results (Ntegeka and Willems, 2008).

\section{RESULTS}

\subsection{All season anomalies}

The results on SST ENSO anomalies show inter-annual oscillations from about 6-7 years with significant anomalies for the periods 1963-1968 (low anomaly), 1982-1984, 1992-1996 (high anomaly); see also Torrence et al. (1999). The SST TSA and Brazil rainfall anomalies show decadal multi-decadal oscillations with low significance in anomalies except a few events that are related to ENSO.

\section{Temperature}

Results of anomalies in monthly temperature considering all seasons, show that 13 out of the 16 stations present similar oscillations, but differ in anomaly scale. Stations located at higher elevations (M199, M141, M031) show higher and more significant values of anomalies than the stations which are located in the inter-valley region (M426, M222, M217, M067), which present low and less significant anomalies. The oscillations show a lower temperature period during 1968-1973 and a warmer period during 1978-1984 (Figure 3). The anomaly values at the high elevations overpasses their significance range 2 to 5 times than at inter-andean valley sites. This is assumed to be the effect of orographic and topographic influences that create microclimates in the deep inter-valley region, (Figure 2).

The temperature anomaly patterns at the 13 stations have high correlation with the anomaly patterns of the SST ENSO 1.2 (Pacific coast of Ecuador) and ENSO $3\left(R^{2}=0,61\right.$ and $R^{2}=0,64$ respectively; considering the average correlation of all 13 stations). For some stations higher correlations are found. For the other 3 stations (M206, M139, M625) the correlation values show different behavior; small correlations are found with the ENSO and no correlation with the other climate external influences. The correlation values are shown in Table 2.

The influence of SST ENSO 1.2 on temperature is nearly homogeneous over the basin (Figure 4), apart from the stations M625 and M139. The results at these two stations differ from the other stations, which might be due to a micro-climate caused by terrain and orographic influences. It is also 
observed that the SST TSA is inversely correlated to the SST ENSO 1.2 and the Brazil rainfall along the basin, resulting in a similar homogeneous influence on temperature.

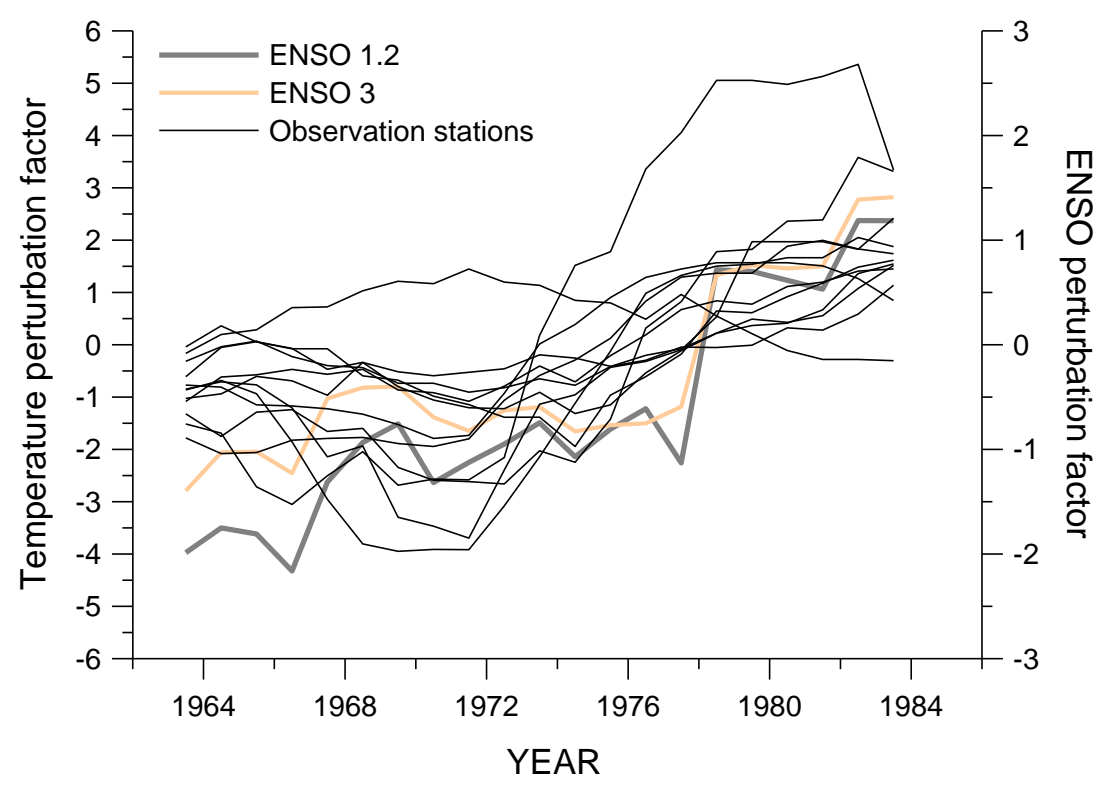

Figure 3. Temperature SST ENSO quantile perturbation analysis results (all seasons, perturbation factor in percent). Observation stations: M031, M032, M045, M050, M067, M138, M140, M141, M197, M199, M217 and M426.

\section{$\underline{\text { Rainfall }}$}

The results on the anomalies in rainfall are more complex than the ones for temperature. Stations with rainfall regimes corresponding to eastern sites (UM1 and UM2) have similar influences. Meanwhile stations located in the inter-andean valley and the high mountainous (páramo) regions (BM1 and BM2) show more heterogeneous behavior. This is due to additional influencing factors such as the location in the catchment, the rainfall regime, the topographical elevation and the orientation of its slope (aspect). However, when the BM1 and BM2 stations are grouped according to their orientation (aspect), more similar results are found. In the inter-andean valley regime (BM1), the stations show similar anomaly patterns for the stations with North-East versus South-West aspect. Same conclusion holds for the high mountain (páramo) regime (BM2).

A first group of 13 of the 25 stations shows similar anomaly patterns. They are located in the downstream eastern part of the basin (UM1 and UM2 rainfall regimes) and at inter-andean valley sites with a North-East aspect corresponding to the BM1 and BM2 rainfall regimes. High anomalies are observed for these stations during 1969-1974 and low anomalies during 1983-1986 (Figure 4a,b). Another group of 9 stations, mainly located in the inter-andean valley regions with South-West aspect, show high anomalies during 1978-1981, 1986-1989 and 1996-2000 and low anomalies during 1965-1974 and in the beginning of the 1990s (Figure 4c). A third group of stations (M420, M418 and M429) shows a different pattern of anomalies with oscillation highs and lows occurring in a more random way in time and with no significant correlation with the large scale climate influences (Figure 4d). The stations with medium and strong Amazon regime (UM1 and UM2) in the eastern part of the basin, together with the sites located in the mountain region BM2 with a North-East aspect, are negatively correlated to the SST ENSO 1.2. The correlation factors for UM1 and UM2 are $\mathrm{R}^{2}=0,67$ and 0,60 respectively, and $\mathrm{R}^{2}=0,53$ for BM2. Also a negative correlation with Brazil rainfall is found. Stations with a North-East aspect in regime BM1 are correlated with SLP Darwin-Tahiti and negatively correlated with the Brazil rainfall with $\mathrm{R}^{2}=0,57$ and 0,48 , respectively. Stations with a South-West orientation are positively correlated with the SST ENSO 1.2 for BM1 $\left(R^{2}=0,35\right)$ and for $\mathrm{BM} 2\left(\mathrm{R}^{2}=0,22\right)$. 
MASKANA, Vol. 2, No. 1, 2011

Table 2. Correlation in temperature and rainfall perturbation factor vs large scale climate influences: all seasons.

\begin{tabular}{|c|c|c|c|c|c|c|c|c|c|c|c|c|c|c|c|}
\hline \multicolumn{8}{|c|}{ Temperature } & \multicolumn{8}{|c|}{ Rainfall } \\
\hline \multicolumn{8}{|c|}{ Large scale climate influence } & \multicolumn{8}{|c|}{ Large scale climate influence } \\
\hline Station & SST & SST & SST & SLP & Brazil & Eastern & SST & Station & SST & SST & SST & SLP & Brazil & Eastern & SST \\
\hline Code & ENSO 1.2 & ENSO 3 & ENSO 3.4 & $\mathrm{D}-\mathrm{T}$ & rainfall & Pacific & TSA & Code & ENSO 1.2 & ENSO 3 & ENSO 3.4 & $\mathrm{D}-\mathrm{T}$ & rainfall & Pacific & TSA \\
\hline M199 & 0.77 & 0.71 & 0.44 & -0.41 & 0.91 & 0.00 & -0.59 & BM1 & & & & & & & \\
\hline M141 & 0.69 & 0.67 & 0.47 & -0.62 & 0.76 & -0.30 & -0.69 & M625 & -0.56 & -0.55 & -0.44 & 0.67 & -0.71 & 0.27 & 0.62 \\
\hline M031 & 0.78 & 0.78 & 0.64 & -0.72 & 0.68 & -0.43 & -0.61 & M541 & -0.50 & -0.50 & -0.33 & 0.71 & -0.82 & 0.23 & 0.68 \\
\hline M197 & 0.70 & 0.70 & 0.52 & -0.68 & 0.74 & -0.32 & -0.77 & M197 & -0.63 & -0.66 & -0.58 & 0.90 & -0.69 & 0.39 & 0.47 \\
\hline M625 & -0.63 & -0.67 & -0.69 & 0.84 & -0.39 & 0.67 & 0.52 & M139 & -0.76 & -0.76 & -0.70 & 0.73 & -0.50 & 0.59 & 0.58 \\
\hline M426 & 0.79 & 0.85 & 0.84 & -0.77 & 0.56 & -0.62 & -0.50 & M140 & 0.43 & 0.37 & 0.29 & 0.25 & -0.73 & 0.38 & 0.57 \\
\hline M067 & 0.75 & 0.83 & 0.87 & -0.80 & 0.50 & -0.69 & -0.50 & M418 & 0.34 & 0.24 & 0.30 & 0.31 & -0.75 & 0.12 & 0.65 \\
\hline M140 & 0.68 & 0.61 & 0.32 & -0.36 & 0.87 & 0.05 & -0.59 & M067 & 0.35 & 0.31 & 0.02 & -0.32 & 0.70 & -0.14 & -0.72 \\
\hline M045 & 0.88 & 0.90 & 0.75 & -0.61 & 0.83 & -0.33 & -0.53 & M426 & 0.65 & 0.61 & 0.61 & -0.40 & 0.09 & -0.60 & -0.31 \\
\hline M139 & 0.04 & 0.01 & 0.01 & 0.44 & 0.01 & 0.44 & 0.66 & M138 & 0.40 & 0.47 & 0.45 & -0.39 & 0.04 & -0.60 & 0.01 \\
\hline M222 & 0.80 & 0.89 & 0.93 & -0.63 & 0.52 & -0.54 & -0.19 & M539 & 0.74 & 0.75 & 0.53 & -0.76 & 0.73 & -0.53 & -0.71 \\
\hline M138 & 0.87 & 0.82 & 0.59 & -0.44 & 0.91 & -0.13 & -0.49 & M420 & 0.10 & 0.02 & -0.15 & 0.10 & 0.11 & 0.01 & -0.34 \\
\hline M050 & 0.87 & 0.89 & 0.79 & -0.71 & 0.77 & -0.45 & -0.59 & M427 & 0.81 & 0.75 & 0.60 & -0.26 & -0.35 & 0.07 & 0.14 \\
\hline M217 & 0.91 & 0.90 & 0.82 & -0.44 & 0.71 & -0.34 & -0.18 & BM2 & & & & & & & \\
\hline M206 & 0.26 & 0.11 & -0.23 & 0.21 & 0.58 & 0.53 & -0.18 & M414 & -0.56 & -0.50 & -0.27 & 0.53 & -0.80 & 0.23 & 0.75 \\
\hline \multirow[t]{14}{*}{ M032 } & 0.69 & 0.78 & 0.82 & -0.87 & 0.45 & -0.71 & -0.62 & M424 & -0.86 & -0.89 & -0.90 & 0.82 & -0.43 & 0.78 & 0.42 \\
\hline & & & & & & & & M141 & 0.33 & 0.30 & 0.11 & -0.16 & 0.37 & -0.31 & -0.35 \\
\hline & & & & & & & & M430 & 0.44 & 0.41 & 0.15 & -0.42 & 0.46 & -0.33 & -0.47 \\
\hline & & & & & & & & M417 & 0.60 & 0.55 & 0.32 & -0.47 & 0.71 & -0.38 & -0.73 \\
\hline & & & & & & & & M429 & -0.60 & -0.58 & -0.61 & 0.53 & -0.26 & 0.42 & 0.39 \\
\hline & & & & & & & & UM1 & & & & & & & \\
\hline & & & & & & & & M583 & -0.81 & -0.84 & -0.89 & 0.76 & -0.39 & 0.70 & 0.41 \\
\hline & & & & & & & & M410 & -0.68 & -0.74 & -0.85 & 0.71 & -0.34 & 0.58 & 0.28 \\
\hline & & & & & & & & M538 & -0.89 & -0.88 & -0.77 & 0.80 & -0.61 & 0.71 & 0.65 \\
\hline & & & & & & & & M222 & -0.87 & -0.85 & -0.75 & 0.77 & -0.63 & 0.65 & 0.63 \\
\hline & & & & & & & & UM2 & & & & & & & \\
\hline & & & & & & & & M050 & -0.77 & -0.77 & -0.59 & 0.79 & -0.82 & 0.51 & 0.70 \\
\hline & & & & & & & & M217 & -0.71 & -0.71 & -0.49 & 0.76 & -0.85 & 0.42 & 0.76 \\
\hline & & & & & & & & M045 & -0.83 & -0.81 & -0.67 & 0.75 & -0.71 & 0.59 & 0.70 \\
\hline
\end{tabular}



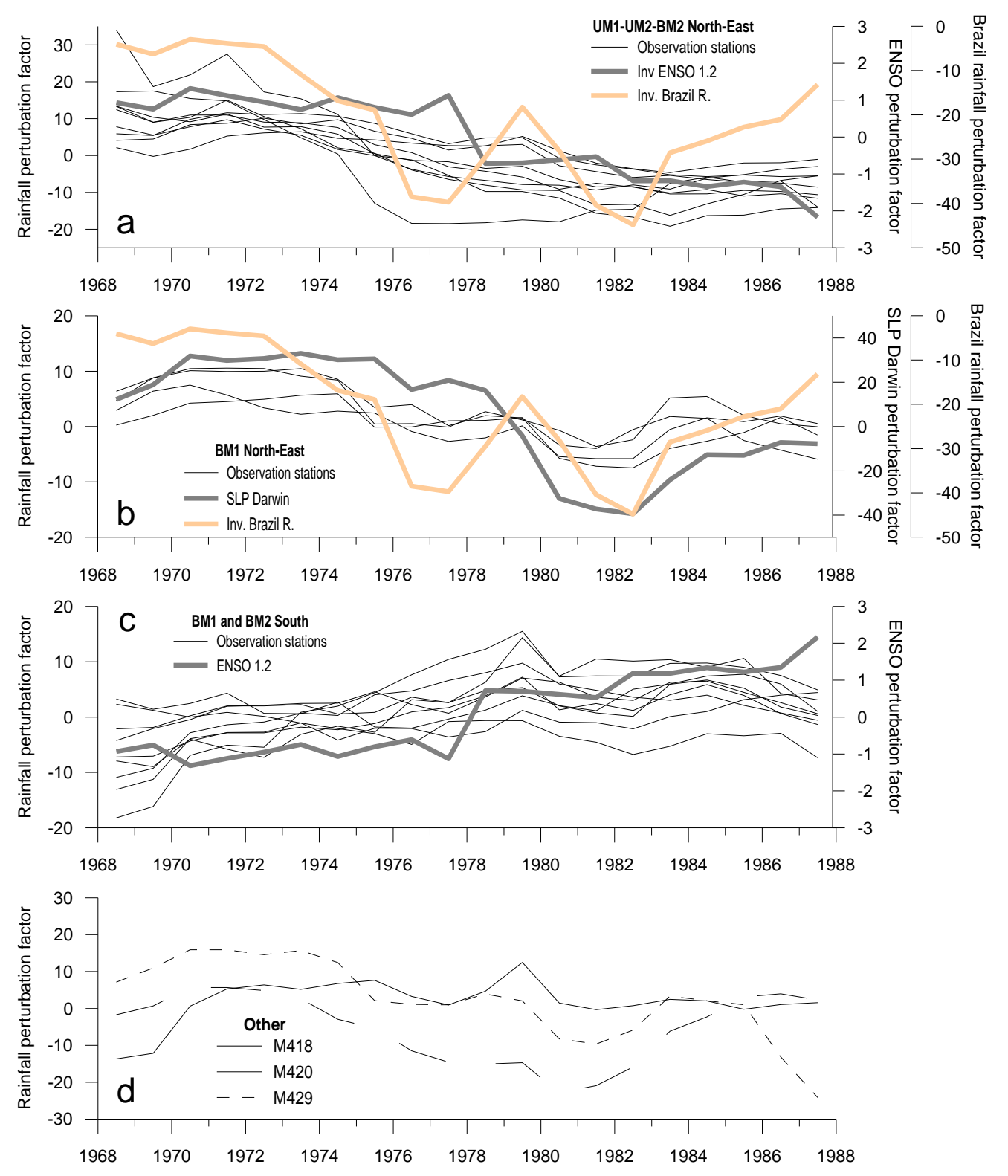

Figure 4. Rainfall, ENSO and large scale climate quantile perturbation analysis results: all seasons. (a) UM1, UM2 and BM2 North-East aspect; (b) BM1 North-East aspect; (c) BM1 and BM2 South aspect; and (d) other. All perturbation factors in percent.

Plotting these different groups (Figure 5), it can be observed that the eastern part of the basin is negatively correlated with the SST ENSO 1.2 and that the Brazil rainfall is positively correlated with the SST TSA. In the inter-andean valley regions and western sites, this influence depends on the terrain orientation (aspect). In summary, it can be concluded that the annual anomalies in the regions UM1, UM2 and BM2 with North-East aspect are strongly negatively correlated with the SST ENSO and negatively correlated with the Brazil rainfall. Region BM1 with North-East aspect shows an inverse influence of the ENSO but has a stronger negative correlation with the Amazon rainfall. Regions BM1 and BM2 with South aspect are positively correlated with the SST ENSO 1.2 but in a less significant way. 
MASKANA, Vol. 2, No. 1, 2011

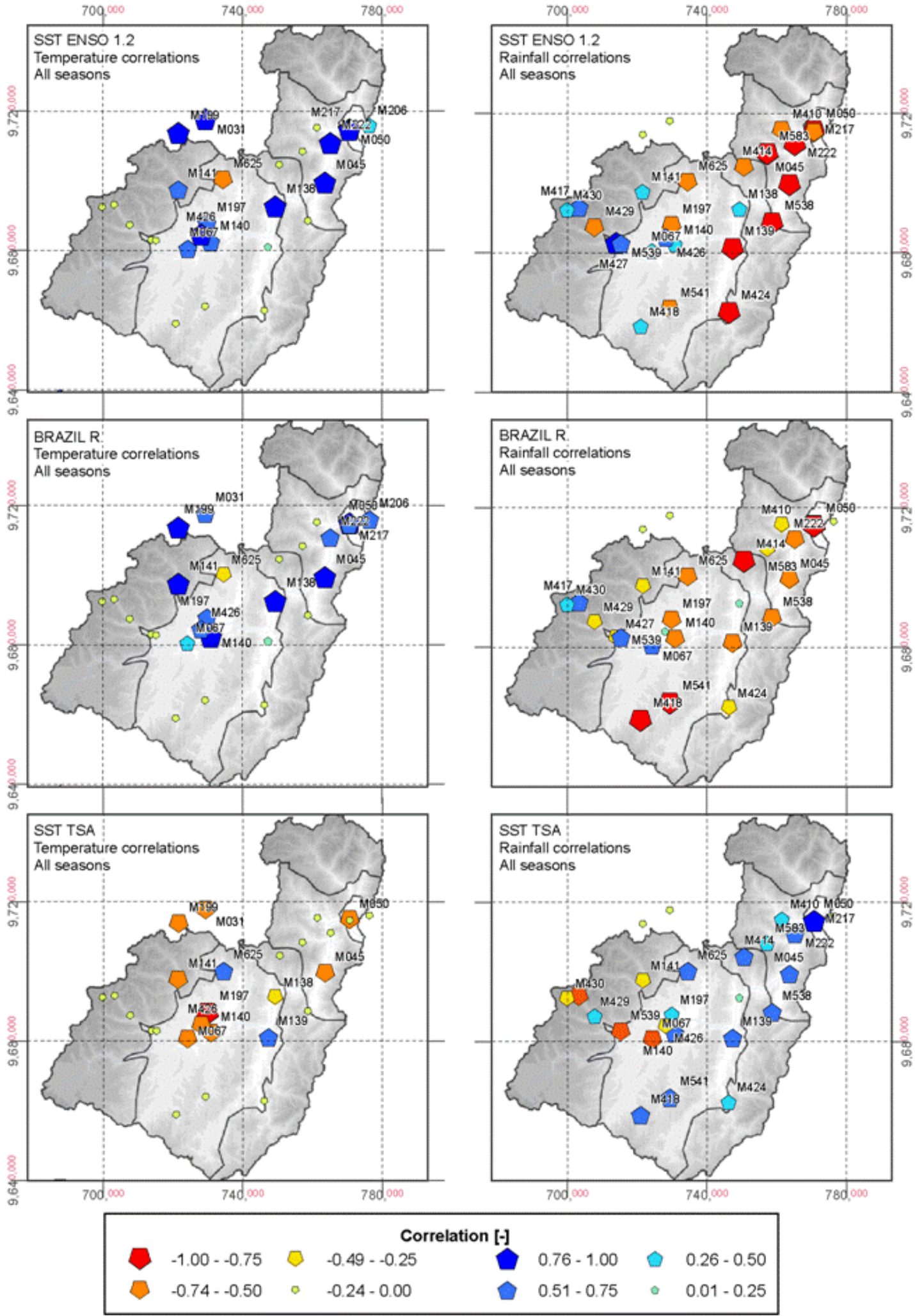

Figure 5. Correlation between anomalies of observed sites and anomalies of different large scale climate influences for temperature (left) and rainfall (right) in all seasons. 


\subsection{Anomalies for specific seasons}

The same analysis was repeated for 3-month periods to estimate the anomaly patterns for different seasons of the year.

\section{Temperature}

Results on the anomalies for specific seasons present similar results when compared to the results for all seasons. This means low temperature anomalies during the years 1969-1973 and high anomalies during 1979-1984, which are mainly influenced by ENSO. The correlations, however, are stronger/weaker for specific seasons. For the period of DJF, 11 of the 16 stations show high correlation with the SST ENSO 1.2 and ENSO $3\left(\mathrm{R}^{2}=0,79\right.$ and 0,78 respectively). For the season of MAM, similar results as for the season DJF are obtained in 13 of the 16 stations but with lower correlation values. These anomalies are positively correlated to the SST ENSO 3 and the Brazil rainfall $\left(\mathrm{R}^{2}=0,77\right.$ and 0,63 respectively). Low temperature anomalies are found during the years 1969-1973 and high anomalies during 1979-1984. When compared with the anomalies for all seasons, more extreme and significant anomalies are found. The strong correlation that the ENSO has in the period of DJF is still present in the period of MAM. The Paute River Basin and the Brazil rainfall are, however, positively correlated in the period of MAM.

During the period of JJA, 10 of the 16 stations show anomaly patterns with lower temperatures during the years 1964-1974 (with a minimum in 1971) and higher values in the period 1978-1986 (with a maximum in 1984) (see Figure 5c). These anomalies are negatively correlated with the Eastern Pacific Oscillation $\left(\mathrm{R}^{2}=0,65\right)$, but less correlated with the ENSO 1.2 oscillation as in the previous periods $\left(\mathrm{R}^{2}=0,52\right)$. These low correlations might imply that local influences could play a larger role than the ENSO during this period. There is a need to further investigate possible sources of climatic influences in the region, especially for this period when the ENSO influence is weak. The anomalies are high and significant in JJA, similar to the period of DJF, despite the fact that the influence of ENSO is weak.

For the period of SON, 10 of the 16 sites show similar results as the season of DJF. Low temperature anomalies are found during the period 1968-1974 (with a minimum in 1971) and high anomalies in the period 1979-1984 (with a maximum in 1982). The anomaly values can differ between stations, showing higher and significant anomaly values for the higher elevation sites. The values are, however, less extreme when compared with other seasons. The anomalies have high correlation with the SST ENSO 3 and ENSO $1.2\left(\mathrm{R}^{2}=0,65\right.$ for both).

\section{$\underline{\text { Rainfall }}$}

In the all seasons analysis, the stations were grouped according to the hydrological regime and orientation (aspect). This resulted in the following groups: (i) Eastern part of the basin and some interandean valley sites with North-East aspect and (ii) some inter-andean valleys and Western sites with South-West aspect. The same analysis is repeated here, but based on the 3-month periods.

The negative correlation with SST ENSO 1.2 and Brazil rainfall, and the positive correlation with the SST TSA found for the first group of stations is stronger for the season of SON. This means high rainfall anomalies in the periods 1969-1973 and 1986-1988 and low rainfall anomalies during 1979-1984. However, negative correlation was also found for stations that belong to regimes UM1 and UM2 with the SST EPO $\left(\mathrm{R}^{2}=0,69\right.$ and 0,44 , respectively). The stations from the regimes BM2 and BM1 with a North-East orientation are also negatively correlated, but in a lower way, with the SST EPO $\left(\mathrm{R}^{2}=0,60\right)$. The positive correlation with the SST ENSO 1.2 in some of the inter-andean valley regions and western sites is stronger in the season MAM (see Figure 6), especially in stations with South or South-East aspect. They show a negative rainfall anomaly during 1965-1973 and a positive rainfall anomaly during 1979-1985. The anomaly values of this group present a direct correlation with the SST ENSO 3 and SST ENSO $1.2\left(\mathrm{R}^{2}=0,61\right.$ and 0,56 , respectively).

In the period of MAM another group of stations with North or North-East aspect shows high anomalies during 1970-1974 and low anomalies during 1985-1990. This group present a negative correlation with the SST ENSO 3 and SST ENSO $1.2\left(\mathrm{R}^{2}=0,54\right.$ and 0,58, respectively). For the 
period of DJF, no clear influence of the climate external influences is shown. This indicates that the high negative correlations found for the all seasons anomalies with ENSO, for most of the stations, are due to rainfall in other periods of the year. Grouping of the stations by regime and/or aspect did not alter these results. This lack of correlation might be caused by the transition of external influences for SON and MAM. However, in DJF two groups of stations were identified. Stations M197, M067, M140, M414 and M045 have high correlation with the Tropical Pacific anomaly $\left(R^{2}=0,58\right)$. The anomalies are high during the periods 1968-1974 and 1984-1986 and low during 1980-1983.

For the period of JJA, the 25 stations show similar oscillations, with high anomalies during 19681976 and low anomalies during 1981-1989. These anomaly values have a negative correlation with the SST ENSO 3 and a positive correlation with the SST EPO $\left(\mathrm{R}^{2}=0,59\right.$ and 0,63 , respectively). When the negative correlation with the SST ENSO 3 is studied separately per rainfall regime, $\mathrm{R}^{2}$ values of $0,53,0,41,0,54$ and 0,52 are found for the BM1, BM2, UM1 and UM2 regions. The period of JJA shows the same behavior than the period of SON but with lower correlations for the SST ENSO 1.2 and Brazil rainfall. The influence of the SST TSA is lower during this period and shows negative correlation.

\section{CONCLUSIONS}

The analysis of anomalies of rainfall and temperature with the external climate influences has shown that historical variations in rainfall and temperature for the stations in the Paute River Basin differ depending on elevation, hydrological regime and orientation (aspect). Historical variations in temperature, when considering all seasons combined, show strong similarities in the results across the basin. Most of the sites show lower temperatures during 1968-1973 and a warmer period during 19781984. The significance of the anomalies in temperature is higher at sites with higher elevations. They are highly correlated with the SST ENSO 1.2 and ENSO 3. For the deep inter-andean valley stations, anomalies and their correlation with the ENSO are less significant. During the months DJF, most of the stations show a stronger correlation with the SST ENSO 1.2. For the other seasons, the influence of ENSO is also present, but less strong. The ENSO influence is lower for the season of JJA. This supports a better understanding of the influence of ENSO on temperature along the Paute River Basin.

The historical variations in rainfall are diverse. Results show that for the eastern stations (Amazon regime) anomaly values are more significant. High anomaly values are found during 19691974 and low values during 1983-1986, which are negatively correlated with the SST ENSO 1.2. For the other stations, the anomalies behave in a more random way in time (less similarity between stations: high and low anomaly values in different periods). Also the significance of these anomalies and their correlation with the large scale climate influences is less clear. The stations from the BM2 region (high mountain regime) with a North-East aspect show strong anomalies (high rainfall during 1969-1974 and low rainfall during 1983-1986) similar to the regions UM1 and UM2. The interandean valley stations located in the region BM1 with North-East aspect, show similar behavior as UM1 and UM2, but with less significant values and lower correlation to large scale climate influences. The stations with South-West aspect, for the regions BM1 and BM2, match in their anomalies: a high rainfall period during 1978-1981 and a low rainfall period during 1965-1974 but less significant than for the other sites and their correlations with the large scale climatic influences are less clear. The season SON shows stronger negative correlations with the SST ENSO 1.2, Brazil rainfall, and SST TSA for the stations located in the UM1 and UM2 regions and the BM1 and BM2 regions with North-East aspect. Meanwhile the season of MAM shows positive correlation with the SST ENSO 1+2 for some Western stations.

This study has given more insight in the climate variability at local scale in the Paute River Basin of the Ecuadorian Southern Andes, after identifying similarities and differences in temporal patterns of temperature and rainfall along the basin. The correlations with climate external influences are simpler for temperature series and more complex for rainfall series. Given that much larger records are available for the climate external influences than for the rainfall and temperature series, 
MASKANA, Vol. 2, No. 1, 2011

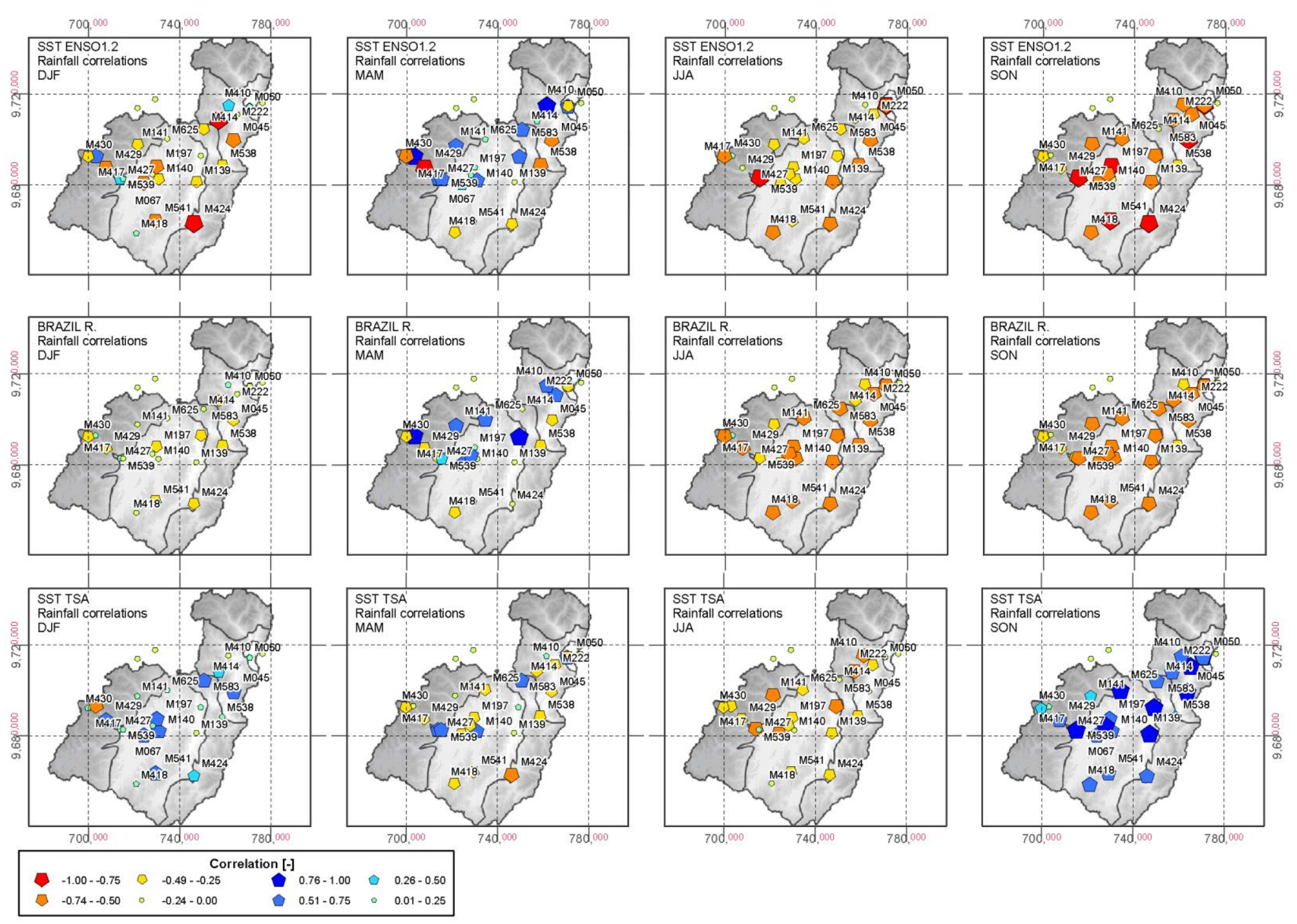

Figure 6. Correlation between anomalies at observed sites and anomalies of different large scale climate influences for rainfall in different seasons. 
these correlations might help to extrapolate the patterns of temperature and rainfall beyond the observation periods.

The quantile perturbation method would also be useful to estimate trends in climate values. However, the usefulness strongly depends on the length of the available data series. In this research, the data series length was limited to 30 years, which is not enough to find several complete oscillation cycles to estimate the significance of recent trends. The data for the more recent years (after the 1990s) was, moreover, unluckily unavailable, except for the three stations mentioned, which have similar trends as their most correlated climate variables. The present research therefore has been limited to the identification of decadal oscillations. The results in this research approach the results in Marengo (2009), in which the Amazon rainfall indicates long-term variations of decadal and multidecadal modes rather than any unidirectional trend towards drier or wetter conditions. The derived insights will clearly help in future research separating trends from natural variability.

\section{ACKNOWLEDGEMENT}

The research was feasible thanks to a grant of the Selective Bilateral Agreement of the Katholieke Universiteit Leuven, Belgium and its cooperation with the University of Cuenca, Ecuador. Special thanks to the staff of the Hydraulics Division of K.U. Leuven and to Felipe Cisneros of PROMAS of the University of Cuenca for the provision of research facilities, data and assistance. Many thanks to Victor Ntegeka for his support with the application of the quantile-perturbation method and to Mauricio Villazon for his support in the rainfall gap filling. Last but not least, many thanks to Prof. Jan Feyen for his kind support in the revision of the manuscript.

\section{REFERENCES}

Bendix, A., J. Bendix, 2006. Heavy rainfall episodes in Ecuador during El Nino events and associated regional atmospheric circulation and SST patterns. Adv. Geosci., 6, 43-49.

Buytaert, W., M. Vuille, A. Dewulf, R. Urrutia, A. Karmalkar, R. Celleri, 2010. Uncertainties in climate change projections and regional downscaling in the tropical Andes: implications for water resources management. Hydrol. Earth Syst. Sc., 14, 1247-1258.

Carter, R.W., M.A. Benson, 1970. Concepts for the design of a streamflow data program. U.S. Geological Survey, Open-file report, 20 pp.

Celleri, R., P. Willems, W. Buytaert, J. Feyen, 2007. Space-time variability of rainfall in the Paute River Basin of South Ecuador. Hydrol. Process., 21, 3316-3327.

Coltorti, M., C.D. Ollier, 2000. Geomorphic and tectonic evolution of the Ecuadorian Andes. Geomorphology, 32, 1-19.

Francou, B.,M. Vuille, V. Favier, B. Cáceres, 2004. New evidence for an ENSO impact on lowlatitude glaciers: Antizana 15, Andes of Ecuador, $0^{\circ} 28^{\prime}$ S. J. Geophys. Res., 109, doi:10.1029/2003JD004484.

Galarraga-Sanchez, R., 2000. Informe Nacional sobre la gestion del agua en el Ecuador. Comite Asesor Tecnico de America del Sur (SAMTAC). Global Water Partnership (GWP), QuitoEcuador, February 2000, 80 pags., http://www.unesco.org.uy/phi/vision2025/Ecuador.pdf.

Le Goulven, P., T. Ruf, H. Ribadeneira, 1987. Presentación del Proyecto INERHI (Instituto Ecuatoriano de Recursos Hidraulicos, Ecuador) - ORSTOM (Office de la Recherche Scientifique et Technique d'Outre-Mer, France), Quito, Ecuador, May 1987, 23 pp.

Makhuvha, T., G. Pegram, R. Sparks, W. Zucchini, 1997. Patching rainfall data using regression methods I. Best subset selection, EM and pseudo-EM methods: theory. J. Hydrol., 198, 289-307. 
Marengo, J.A., 2009. Long-term trends and cycles in the hydrometeorology of the Amazon basin since the late 1920s. Hydrol. Process., 23, 3236-3244.

Ntegeka, V., P. Willems, 2008. Trends and multidecadal oscillations in rainfall extremes, based on a more than 100-year time series of 10 min rainfall intensities at Uccle, Belgium. Water Resour. Res., 44, doi:10.1029/2007WR006471.

Ontaneda, G., G. García, A. Arteaga, 2002. Evidencias del Cambio Climático en Ecuador. Actualización. Comité Nacional sobre el Clima GEF-PNUD. Ministerio del Ambiente. Proyecto ECU/99/G31 Cambio Climático-Fase II., Quito, Ecuador, 92 pp.

Parry, M.L., O.F. Canziani, J.P. Palutikof, P.J. Van der Linden, C.E. Hanson, 2007. Contribution of Working Group II to the Fourth Assessment Report of the Intergovernmental Panel on Climate Change. Cambridge University Press, Cambridge, United Kingdom and New York, USA, 976 pp.

Paulhus, J.L.H., M.A. Kohler, 1952. Interpolation of missing precipitation records. Mon. Weather Rev., 80, 129-133.

Romero, R., J.A. Guijarro, C. Ramis, S. Alonso, 1998. A 30-year (1964-1993) daily rainfall data base for the Spanish Mediterranean regions: first exploratory study. Int. J. Clim., 18, 541-560.

Solomon, S., D. Qin, M. Manning, Z. Chen, M. Maqruis, K.B. Averyt, M. Tignor, H.L. Miller, 2007. Contribution Working Group I to the Foruth Assessment Report of the Intergovernmental Panel on Climate Change. Cambridge University Press, Cambridge, United Kingdom and New York, USA, 996 pp.

Torrence, C., P.J. Webster, 1999. Interdecadal Changes in the ENSO-Monsoon System. J. Climate, 12, 2679-2690.

Torres, P., 2004. Correlación como herramienta para analizar la distribución de precipitación en la cuenca del rio Paute. MSc Thesis, Programa para el Manejo del Agua y del Suelo, Universidad de Cuenca, Cuenca, Ecuador, 80 pp.

USACE, 1971, HEC-4 Software Monthly Streamflow Simulation. User's Manual. U.S. Army Corps of Engineers, Hydrologic Engineering Center, Davis, California., 104 pp.

Villar, J.C., J. Roncahil, J.L. Guyot, G. Cochonneau, F. Naziano, W. Lavado, E. De Oliveira, R. Pombosa, P. Vauchel, 2009. Spatio-temporal rainfall variability in the Amazon basin countries (Brazil, Peru, Bolivia, Colombia and Ecuador). Int. J. Climatol., 29, 1574-1594.

Villazon, M. F., P. Willems, 2010. Filling gaps and daily disaccumulation of precipitation data rainfall-runoff model. Proc. 4th Int. Sci. Conf. BALWOI 2010 on Water Observation and Information Systems for Decision Support, Rep. Macedonia, 25-29 May 2010.

Vuille, M., R.S. Bradley, F. Keiming, 2000. Climate variability in the Andes of Ecuador and its relation to tropical Pacific and Atlantic sea surface temperature anomalies. J. Climate, 13, 25202535.

Vuille, M., B. Francou, P. Wagnon, I. Juen, G. Kaser, B.G. Mark, R.S. Bradley, 2008. Climate change and tropical Andean glaciers: Past, present and future. Earth-Sci. Rev., 89, 79-96. 